\title{
The Exposition of an Irresponsible Expert Witness in a Developing Country
}

\author{
Wilson I B Onuigbo* \\ Department of Pathology, Medical Foundation \& Clinic, Nigeria \\ *Corresponding author: Wilson I B Onuigbo, Department of Pathology, Medical Foundation \& Clinic, 8 Nsukka Lane, Enugu-410000, Nigeria

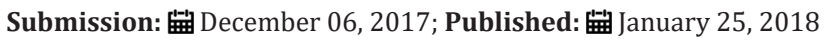

\begin{abstract}
By 1986, an Editor vouched that, concerning research on the requested reprint (RR), I was the foremost he could trace! On the personal side, I did collect a mini-library to the extent of being able to prove the lingua franca status of the English language. In this context, I possess a reprint as the irresponsible expert witness. Moreover, I am in a position to expose such a character in this developing community without naming name of course.

Keywords: Reprint; Request; Word; Example; Irresponsible; Evidence
\end{abstract}

\section{Introduction}

By 1986, The Editor of English for Specific Purposes published that, concerning researches on the requested reprint (RR) [1], I was the world's leading researcher! Perhaps, to exemplify his assertion, it sufficed for me to use the single English word, "uneventful," to show that the English Language is the lingua franca. Therefore, it is hypothesized that Robert Brent's reprint in my possession [2], namely, "The Irresponsible Expert Evidence" [3], can serve as a cornerstone to exemplify a local expert witness who was "irresponsible" repeatedly in a murder case. Of course, he should be called Dr. X

\section{Case Report}

The case involved two young men who fought in a compound and one of them died of knife wounds. I was the adviser to the lawyer of the accused. I detected evidences of irresponsibility of $\mathrm{Dr}$ $\mathrm{X}$ as follows:

1. According to him, "There was no evidence of struggle." Clothing is a known material for such an assessment and yet the naked embalmed body was what was autopsied by Dr X, for added on cross examination that "The deceased was naked when I saw it."

2. "He had a very deep cut on the left shoulder." This is an emotive statement. How deep is "very deep cut?" Accurate measurement is required.

3. The cut was recorded as "severing the lateral head of the pectoralis muscle." There are two pectoralis muscles, the major and the minor. The minor is the one that has a head (not lateral head). It lies beneath the major muscle. Therefore, any description of it must accompany a description of the wound of the major muscle.
4. The cut was stated as "severing also the neuro-vascular bundle in the axilla which includes the brachial vein, brachial artery, and brachial nerve." Calling these "brachial" is wrong because the "axilla" was the stated site. Even if nomenclature is forgiven, the severance of the big artery and vein would have caused death on the spot! And yet the injured victim was transported across the town, past a Teaching Hospital, and then taken to a private clinic. Consequently, the described injuries were not in consonance with the eventuality.

5. The wound was further described as being "obviously caused by a hard and sharp object used with considerable force from the back-side." The Concise Oxford Dictionary renders back-side as a word "not used in polite society" for it means buttocks. Dr X could not have meant the buttocks when describing shoulder wounds! He should have said "back" per se or posterior.

6. "This incision is about 6.5 centimeter in length." I am afraid that an approximation is not enough. Experts deal with precise measurements.

7. "The cut went through the 1 st and 2 nd ribs." If this had occurred, the cavity of the chest would have been penetrated and the victim would have died of pneumothorax, i.e., distension of the chest cavity with air, leading to the collapse of the whole lung. Of course, no mention of the state of the lung was made.

8. "The chemicals are used for the preservation of the internal organs and the external body. It is just formalin that is used. Just one chemical." This statement is false. It is a highly pungent material which has to be much diluted with water, salt and glycerine being added also. Patently, Dr X answer made during cross examination shows basic ignorance. 
9. "The chemicals are poisonous. And poison is destructive to living tissue." This answer also manifests ignorance, seeing that not living tissue but dead tissue was embalmed. In fact, the concentration of formalin used is such that its osmotic pressure is guaranteed to be the same for both living and dead tissues. Such a concentration ensures for all tissues an equable environment.

10. According to Dr X, "Pathology is the study of morbidity of organ tissue system in a dead body or in living human being. It is slightly different from forensic science which is more of traumatology in human being diseases which may have resulted in death - i.e., this is pathology." This definition is weak indeed. Forensic science is definitely not "more of traumatology."

11. "The wound was inflicted from the back and that is the most likely place from where it was inflicted." This is the summation of a medical witness bent on showing that the deceased was attacked from the back. Alas! This is not tenable because the injuries were at the front of the body! Verily, verily, the pectoral muscles cover the front of the chest i.e., the anterior part. Being irresponsible, Dr X sought to prove homicide rather than to exclude accident; he forgot that he had stated on oath that the wound ran "from the upper-onethird of the left deltoid muscle through the anterior axillary part of the arm." It must be an acrobatic murderer who could stay at the back of the victim and then strike him in front!

Again, look at the omissions. Firstly, there was no statement on the appearance of the conjunctiva which would have supported greatness of loss of blood. Secondly, there was no statement on the condition of the chest organs which would have revealed if the lung was collapsed or if the coverings of the heart were distended with blood (tamponade). These two areas, if carefully examined, would have accounted for the stated lapse of time between the infliction of injury and death.

\section{Discussion}

Now, we are faced with the body of a dead youth. Therefore, one can only conjecture what might have transpired.

Apparently, the accused and the deceased were youths living in the same neighborhood. Things fell apart and the deceased accosted the accused with a knife. During the face to face struggle to wrest the knife, it struck the dead one. Almost certainly, the wound was so small that death did not occur straightaway but after an appreciable time. Unfortunately, there was no recourse to the neighboring Teaching Hospital. Rather, a private clinic out of town was journeyed to. Thereafter, fate intervened to bring about the fatal result. Hence, as I have to conclude, death should not have occurred in this case.

\section{References}

1. Swales J (1986) ESP in the big world of reprint requests. Eng Specific Purposes 5(1): 81-85.

2. Onuigbo WIB (2014) The word "uneventful" exemplifies the lingua franca status of English. World J Dev Country Edu Res 1: 1-5.

3. Brent RL (1982) The irresponsible expert witness: A failure of biomedical graduate education and professional accountability. Pediatrics 70(5): 754-762. 